\title{
Communication
}

[Comunicação]

\section{New host for the parasitoid Pachycrepoideus vindemmiae (Rondani) (Hymenoptera: Pteromalidae) in Brazil}

\author{
[Novo hospedeiro para o parasitóide Pachycrepoideus vindemmiae (Rondani) \\ (Hymenoptera: Pteromalidae) no Brasil].
}

\section{C.H. Marchiori, O.M. Silva Filho}

\author{
Centro Federal de Educação Tecnológica de Urutaí-UNED \\ Caixa Postal 92 \\ 75650-000 - Morrinhos, GO
}

The Pteromalidae is cosmopolitan in distribution and is one of the largest families of Chalcidoidea, containing over 3000 recognized species in nearly 600 genera. The modes of carnivore encountered in the family are very diverse, encompassing idiobiosis and koinobiosis, ectoparasitism and endoparasitism, solitary and gregarious and primary and secondary parasitoids (Gauld and Bolton, 1988; Hanson and Gauld 1995).

The hosts Pteromalidae include: Hemiptera, Neuroptera, Coleoptera, Lepidoptera, Diptera, Siphonaptera, Hymenoptera, Dermaptera and Homoptera. They attack eggs, larvae, pupae or, rarely, adults. The main contribution of pteromalids is their control over muscoid flies, especially the house-fly and the stable fly (Gauld and Bolton, 1988; Hanson and Gauld 1995).

Pachycrepoideus vindemmiae (Rondani) (Hymenoptera: Pteromalidae) is considered a solitary parasitoid containing a great number of Diptera in the families Anthomyiidae, Calliphoridae, Muscidae, Sarcophagidae, Tachinidae and Tephritidae. This species presents a diversified (cosmopolitan) distribution and it has been found in North America and Africa (Rueda and Axtell, 1985; Marchiori et al., 2002, 2003).

The objective of this note is to relate the new host for the parasitoid P. vindemmiae in Brazil.
The study was carried out in the city of Itumbiara, GO $\left(18^{\circ} 25^{\prime} \mathrm{S}-4^{\circ} 13^{\prime} \mathrm{W}\right)$, Brazil. Fresh feces were collected immediately after emission and mixed in 20-liter pails. Artificial 2liter fecal pats were produced and placed inside 10 plastic buckets $(40 \mathrm{~cm}$ diameter and $12 \mathrm{~cm}$ height), containing a layer of $5 \mathrm{~cm}$ of soil collected from the pasture. A few holes were made in the bottom of the buckets to allow water drainage. The buckets were then taken to the pasture, to serve as substratum for the colonization and development of flies, and stayed there for after ten days of exposure and then, were taken to the laboratory. The buckets were covered with a fine mesh fabric, and kept in the laboratory where the pupae were extracted by water flotation. The pupae were individually placed in gelatin capsules (number 00) and kept until the emergence of the adult flies and of their parasitoids.

From June to August 2004, two specimens of $P$. vindemmiae were collected in 16 pupae of Cyrtoneurina pararescita Couri (Diptera: Muscidae). The percentage of parasitism was $125 . \%$. The fact to attack several dipterous, favors $P$. vindemmiae permanence in the environment, improving its potential as biological agent (Marchiori et al., 2002).

Pachycrepoideus vindemmiae is considered a pupae parasitoid of a great number of Diptera, including species of genus: Anastrepha,

Recebido em 29 de setembro de 2004

Aceito em 22 de novembro de 2006

E-mail: chmarchiori@yahoo.com.br 
Calliphora, Ceratitis, Chrysomya, Drosophila, Fannia, Haematobia, Hylemya, Lucilia, Oxysarcodexia, Paratheresia, Phaenicia, Phormia, Poecilosomella, Peckia, Rhagoletis, Sarcophagula and Sarcodexia (Hanson and Gauld, 1995; Marchiori, 2000; Marchiori et al., 2000, 2002, 2003).

For control fly, the natural regulators can be used, such as parasitoids that are the responsible agents for the reduction of the synanthropic fly populations. This paper registers the first occurrence of parasitoid $P$. vindemmiae in pupae of C. pararescita in Brazil.

Keywords: insecta, Diptera, Hymenoptera, biological control

\section{RESUMO}

Relatou-se um novo hospedeiro para o parasitóide Pachycrepoideus vindemmiae (Rondani) (Hymenoptera: Pteromalidae) em fezes bovinas no Brasil. As pupas foram obtidas pelo método de flutuação. Elas foram colocadas, individualmente, em cápsulas de gelatina e mantidas até a emergência das moscas elou parasitóides. A porcentagem total de parasitismo foi de 12,5\%. Este trabalho registra a primeira ocorrência de P. vindemmiae em pupas de Cyrtoneurina pararescita Couri (Diptera: Muscidae) no Brasil.

Palavras-chave: Insecta, Diptera, Hymenoptera, controle biológico

\section{REFERENCES}

GAULD, I.D.; BOLTON, B. The Hymenoptera. Oxford: Oxford University, 1998. 331p.

HANSON, P.E.; GAULD, I.D. The Hymenoptera of Costa Rica. Oxford: Oxford University, 1995. 893p.

MARCHIORI, C.H. Parasitóides de estágios imaturos de dípteros sinantrópicos coletados em vários ambientes em Itumbiara-GO. Acta Scient., v.22, p.655-661, 2000.

MARCHIORI, C.H.; OLIVEIRA, A.M.S.; MARTINS, F.F. et al. Ocorrência de moscas frugívoras (Diptera: Tephritidae e Lonchaeidae) e seus parasitóides em Itumbiara-GO. Arq. Inst. Biol. São Paulo, v.67, p.139-141, 2000.

MARCHIORI, C.H.; PEREIRA, L.A.; SILVA FILHO, O.M. et al. Pachycrepoideus vindemmiae (Rondani) (Hymenoptera: Pteromalidae) as parasitoid of Diptera, in Brazil. Arq. Bras. Med. Vet. Zootec., v.54, p. 665-667, 2002.

MARCHIORI, C.H.; PEREIRA, L.A.; SILVA FILHO, O.M. Primeiro relato do parasitóide Pachycrepoideus vindemmiae (Rondani) (Hymenoptera: Pteromalidae) parasitando pupas de Sarcodexia lambens Wiedemann (Diptera: Sarcophagidae). Cienc. Rural, v.33, p.173-175, 2003.

RUEDA, L.M.; AXTELL, R.C. Guide to common species of pupal parasites (Hymenoptera: Pteromalidae) of the house fly and other muscoid flies associated with poultry and livestock manure. Technical Bulletin, 278. North Carolina Agricultural Research Service, 1985. 88p. 